\title{
THE GIANT TICKS OF THE MALAYAN RHINOCEROSES; WITH A NOTE ON IXODES WALCKENAERII Gervais
}

\author{
By J. BeqUAERT
}

Department of Tropical Medicine and

Museum of Comparative Zoölogy, Harvard University

In January, 1932, Major Arthur S. Vernay obtained, in Lower Perak, for the British Museum, one of the few remaining specimens of the Sunda Rhinoceros, Rhinoceros sondaicus Desmarest. At the suggestion of my friend and colleague, Harold J. Coolidge, Jr., he undertook to collect the ecto- and endoparasites of this animal. The helminths have been reported upon by my colleague, Dr. Jack H. Sandground (1933, Jl. of Parasitology, XIX, pp. 192-204). Of ectoparasites, only numerous ticks were found; but shortly after the animal was shot, a number of horse-flies (Tabanus brunneus Macquart) were observed biting through the thick hide.

More recently (June, 1933) Major Vernay commissioned Major Rawley to secure, if possible, another $R$. sondaicus. An animal believed to be of that species was located in Selangor; but, after being shot, it proved to be a Sumatran Rhinoceros, Rhinoceros sumatrensis Cuvier. Again the only ectoparasites met with were ticks; these were very few in number, eight in all being collected.

Since the ticks obtained from these two Rhinoceroses belong to two different species, one of which is as yet imperfectly known, some notes on these parasites may be of interest. I am much indebted to Major Vernay, Major Rawley, and Mr. Coolidge for the efforts they made in order to secure the specimens; and to Dr. P. H. Hodgkin, Entomologist, Institute for Medical Research, Kuala Lumpur, for preserving and mailing them. 


\section{Amblyomma crenatum Neumann}

Amblyomma crenatum Neumann, 1899, Mém. Soc. Zool. France, XII, p. 214, fig. 52 ( 9 ; off a Rhinoceros supposedly from the Cape of Good Hope) ; 1901, Loc. cit., XIV, p. 297 ( o o ; Sumatra; no host); 1911, Das Tierreich, Lief 26, Acarina, Ixodidæ, p. 77, fig. 34 (옹 o). Robinson, 1926, Ticks, IV, Amblyomma, pp. 12, 21 and 75, figs. 32-33 ( ㅇ ㅇ o).

Amblyomma subluteum Neumann, 1899, Mém. Soc. Zool. France, XII, p. 263 ( $\mathrm{o}$; two without locality, one of them supposedly off an African Rhinoceros).

? Acarus elephantinus Linnaeus, 1758, Syst. Nat., 10th Ed., I, p. 615 ("Habitat in India", no host) ; 1767, Loc. cit., 12th Ed., I, pt. 2, p. 1022 . Gervais, 1844, in Walckenaer, Hist. Nat. Ins. Aptères, II, p. 250. Neumann, 1911, Das Tierreich, Lief. 26, Acarina, Ixodidae, p. 126. A. C. Oudemans, 1926, Tijdschr. v. Entom., LXIX, Suppl., p. 95; 1929, Loc. cit., LXXII, Suppl., p. 207 (with references to the older literature). Not of Schrank, 1776.

? Ixodes elephantinus Fabricius, 1805, Syst. Antl., p. 351. ? Amblyomma elephantinum C. L. Koch, 1844, Arch. f. Naturgesch., X, pt. 1, p. $230 ; 1847$, Uebersicht des Arachnidensystems, IV, p. 19. Neumann, 1899, Mém. Soc. Zool. France, XII, p. 282.

Specimens Examined.-Twenty-four males and twelve females (two fully engorged), off Rhinoceros sondaicus Desmarest, shot four miles north of Teluk Anson and south of the Sungei Lampan, Lower Perak, Federated Malay States (Major Arthur S. Vernay and Dr. P. H. Hodgkin).

The true country of origin and correct host of $A$. crenatum are now definitely established with this material. The information available thus far was summarized by Robinson as follows: "Amblyomma crenatum is an African species and the only known host is the Rhinoceros. Neumann's earlier description of the female was based on a single specimen off Rhinoceros, Cape of Good Hope (Paris Mus.); his description of $A m b$. subluteum was based on two males, one 
of unknown origin, the other off Rhinoceros, Africa. The Berlin Museum collection contains 2 males and 2 females labelled as having been collected by Mösch, in Sumatra. It would seem improbable that this tick is to be found in two parts of the world so remote as Africa and Sumatra without its occurrence being recorded in intermediate parts, and the indication of origin of the Berlin specimens is probably erroneous." The present collection from Perak shows, on the contrary, that the locality "Sumatra" was correct, while there is no reliable evidence of this tick occurring in Africa. Neumann's specimens were most likely obtained from animals kept in captivity in Europe. Ticks have frequently been collected in large numbers in Africa from both the White and the Black Rhinoceros; but, so far as I know, A. crenatum was never found among them. ${ }^{1}$

$A$. crenatum is one of the largest ticks in existence. In our series of 24 males, the scutum of the largest measures $9 \mathrm{~mm}$. in length (not including the capitulum) and $7.8 \mathrm{~mm}$. in greatest width, and that of the smallest $5 \mathrm{~mm}$. and 4.8 $\mathrm{mm}$. respectively. It is noteworthy that the smaller the specimen, the more the scutum approaches the perfect orbicular shape. The 10 unengorged females are 8 to $9 \mathrm{~mm}$. long (without the capitulum) and 7 to $8 \mathrm{~mm}$. wide, the scutum proper being about the same size in the largest and smallest specimens. Two engorged females are enormous, reaching 21 and $22 \mathrm{~mm}$. in length (without the capitulum), $20 \mathrm{~mm}$. in greatest width, and 16 and $17 \mathrm{~mm}$. in thickness. Capitulum and legs also are unusually long. The coloration is remarkably uniform in the series seen and agrees well with Robinson's account. The most remarkable feature is the absence of metallic spots in the male, while the female has three distinct coppery areas, one in each corner of the scutum, that of the apical corner the largest.

The holotypes of $A$. crenatum ( $q$ and of $A$. subluteum ( $\delta$ ) are at the Paris Museum.

I strongly suspect that Linnaeus based the following

'I am unable to account for Neumann's including "Liberia" in the range of $A$. crenatum (1911, Das Tierreich, Lief. 26, p. 78), since there is no Rhinoceros in that country and he does not mention it in his earlier papers. 
description of his Acarus elephantinus upon A. crenatum: "A. orbicularis depressus: macula baseos ovata. Habitat in India. Magnitudo seminis Lupini albi, depressus, lividus, margine crasso, subtus utrinque 3 sulcis. Macula baseos nigra, ovata, trifida." No host is mentioned and the name refers, not to the supposed host, as Houttuyn surmised, but to the unusual size ("elephantine"), this being one of the largest ticks known to Linnaeus. In answer to an inquiry concerning this tick, Professor Ivar Arwidsson writes me that the type is not in Linnaeus' collection at the Zoological Museum of the University of Uppsala. Perhaps it is kept at the Linnaean Society of London, a point which I have not yet been able to investigate.

\section{Amblyomma infestum infestum C. L. Koch}

Amblyomma infestum C. L. Koch, 1844, Arch. f. Naturgesch., X, pt. 1, p. 226 ( o o ; no host; Bintang Island near Singapore); 1847, Uebersicht des Arachnidensystems, IV, p. 68, Pl. XII, figs. 41-42 ( o ô).

Amblyomma infestum infestum Schulze, 1932, Zeitschr. f. Parasitenk., IV, pt. 3, p. 468 ( 우 of ; after Koch's types). Amblyomma testudinarium Robinson, 1926, Ticks, IV, Amblyomma, pp. 17, 23 and 253 (in part; not the description and figures).

Specimens Examined.-One male and three females (two partly engorged), off Rhinoceros sumatrensis Cuvier, shot on the Bernam River, Selangor, Federated Malay States (Major Rawley).

A. infestum is a much smaller tick than $A$. crenatum, with the capitulum and legs of normal length.

P. Schulze has recently claimed (1932, Zeitschr. f. Parasitenk., IV, pt. 3, p. 468) that the tick described and figured by Robinson (1926) as A. testudinarium, was not Koch's species of that name, but a new tick, which he calls A. fallax P. Schulze. Robinson's specimens came from Mouse-Deer (Tragulus sp.) at Biserat, Jalor, Federated Malay States. P. Schulze also attempts to separate infestum Koch and testudinarium Koch as distinct races of a 
species for which he uses the name A. infestum (because it comes before testudinarium on the same page of Koch's paper). Although I have seen no ticks agreeing with Robinson's descriptions and figures, I am inclined to believe that Schulze was correct in introducing $A$. fallax as a new species. At any rate, the male off Sumatran Rhinoceros ventrally lacks the small muscular scutes shown in Robinson's figure, while the peltæ run parallel with the festoons (in Robinson's figure they are oblique, slightly salient at the postero-internal angles. In the three females, the inner margin of the scapulæ is yellowish (not brown, as in Robinson's figure); and the median anterior area of the scutum is almost wholly yellowish (not dark, as in Robinson's figure), although I am not able to see that the yellow color forms two longitudinal stripes.

I am, however, by no means convinced that infestum, proper, and testudinarium are racially distinct. Obviously, Schulze's material was insufficient to show that they are geographically segregated. Of infestum, proper, he saw only Koch's types from Bintang Island near Singapore, one of the Rhio Archipelago, not 75 miles off the Northeast coast of Sumatra. Of testudinarium, he saw, in addition to Koch's type from "Java," 4 males and 4 females from Soekaranda, Sumatra.

The male of infestum, proper, is said to be smaller (length, including palpi, $6 \mathrm{~mm}$.; width, $5 \mathrm{~mm}$.), with much white enamel among the coarse punctures of the alloscutum. That of testudinarium would be larger ( 8 by $6 \mathrm{~mm}$.), with reduced enamel among the coarse punctures. The single male from Selangor measures $7 \mathrm{~mm}$. (with the palps) by $4.8 \mathrm{~mm}$., and the enamel is quite extensive. According to Schulze, in the female of infestum, proper, the scutum measures 3 by $5 \mathrm{~mm}$. and has the scapular stripe well-defined, dark brown. In that of testudinarium the scutum is larger ( 4 by $5 \mathrm{~mm}$.), with the scapular stripe obsolete, pale brown. In all three females from Selangor the scutum measures 3 by $4.5 \mathrm{~mm}$.; but the scapular stripes (on the anterior margin, between the scapulæ and the eyes) are dark brown and sharp in two specimens, very faint and pale in the third. While the Selangor specimens are un- 
doubtedly typical infestum, the value of testudinarium as a distinct race remains a question.

In the foregoing bibliography, I have not included Neumann's references to A. testudinarium $(1899 ; 1901 ; 1911)$, nor those of Krijgsman and Ponto $(1931 ; 1932)$, since these authors may have confused more than one species under that name. Neumann (1901) synonymized with his testudinarium, Ixodes auriscutellatus Koningsberger (1900, Teysmannia, XI, pt. 1, p. 6) and later (1911) also Amblyomma compactum Neumann (1901, Mém. Soc. Zool. France, XIV, p. 296 ; o ; Sumatra; no host). The standing of these two names remains open to discussion. Robinson's many locality and host records of testudinarium probably cover more than one species. In view of this fact the true distribution and range of hosts of $A$. infestum cannot be given.

\section{Hyalomma (?) walckenaerii Gervais}

Ixodes walckenaerii Gervais, 1842, Ann. Soc. Ent. France, XI, Bull. Séances, p. xlvii (off Rhinoceros ; without description) ; 1844, in Walckenaer, Hist. Nat. Ins., Aptères, III, p. 246, Pl. XXXIV, fig. 11 (no sex; no locality, off a rhinoceros of unknown species). Neumann, 1911, Das Tierreich, Lief. 26, Acarina, Ixodidae, p. 133. Amblyomma (?) walckenaerii Neumann, 1899, Mém. Soc. France, XII, p. 279.

Gervais' species is as yet unrecognized. Neumann merely suggested that it might have been an Amblyomma. The original description reads: "Corps roux-grenat, un peu plus pale en dessous, passant au roux-cannelle ainsi que les pattes qui sont allongées et fauves à leurs articulations; abdomen ridé en dessous; point de taches sur le dos; denticules des machoires médiocres; palpes un peu velus montrant un pore terminal à leur dernier article; ouverture génitale au niveau de la deuxième paire de pattes; hanches de la première paire bispinulées à leur bord postérieur; celles des autres simplement échancrées; stigmates dans une impression en fossette subréniforme à l'aisselle de chaque patte postérieure. Longueur du corps, 0.005 [m]; 
de la patte postérieure, $0.0061 / 2[\mathrm{~m}]$. Cette espèce, dont les hanches antérieures ressemblent à celles de l'Ixode de Savigny, a été prise sur un Rhinocéros dont nous ignorons le nom spécifique; nous l'avons dédiée à $M$. de Walckenaer, de qui nous tenons l'unique exemplaire que nous en avons observé." The rather crude figure represents the ventral side of what appears to be an unengorged female.

Surmising that Gervais' type might be preserved at the Paris Museum, I wrote to Mr. Marc André, who kindly informed me that none of Gervais' ticks are in their collections. Neumann evidently never saw them and I have been unable to trace whether or not they are lost.

I believe, however, that a study of the description and figure might help to recognize the species. Turning first to the Amblyomma known to occur on Rhinoceroses, A. crenatum is ruled out at once by the size, the hind legs of that species measuring 11 to $12 \mathrm{~mm}$. in length. On the other hand, none of the smaller Rhinoceros ticks could be described as having the body "roux-grenat", all being distinctly spotted dorsally. The statement about the color, and even more so the comparison of the coxæ I with those of Ixodes savignyi Gervais, induce me to regard Ixodes walckenaerii as based in all probability upon a female Hyalomma. ${ }^{1}$ Ticks of that genus have been found repeatedly on the African Black Rhinoceros; and P. Schulze bases his Hyalomma planum (1919, Sitzungsber. Ges. Naturf. Fr. Berlin, pp. 195 and 196; $\hat{o}$ o ; Tanganyika Territory) on ticks taken from this host. Might not $H$. planum and $H$. walckenaerii be one and the same species?

1/xodes savignyi was based upon the common cattle Hyalomma of Egypt. According to P. Schulze (1930, Zeitschr. f. Parasitenk., III, pt. 1, p. 28). Hyalomma savignyi (Gervais) is the correct name of the cattle tick which thus far has been called Hyalomma aegyptium (Linnaeus. 

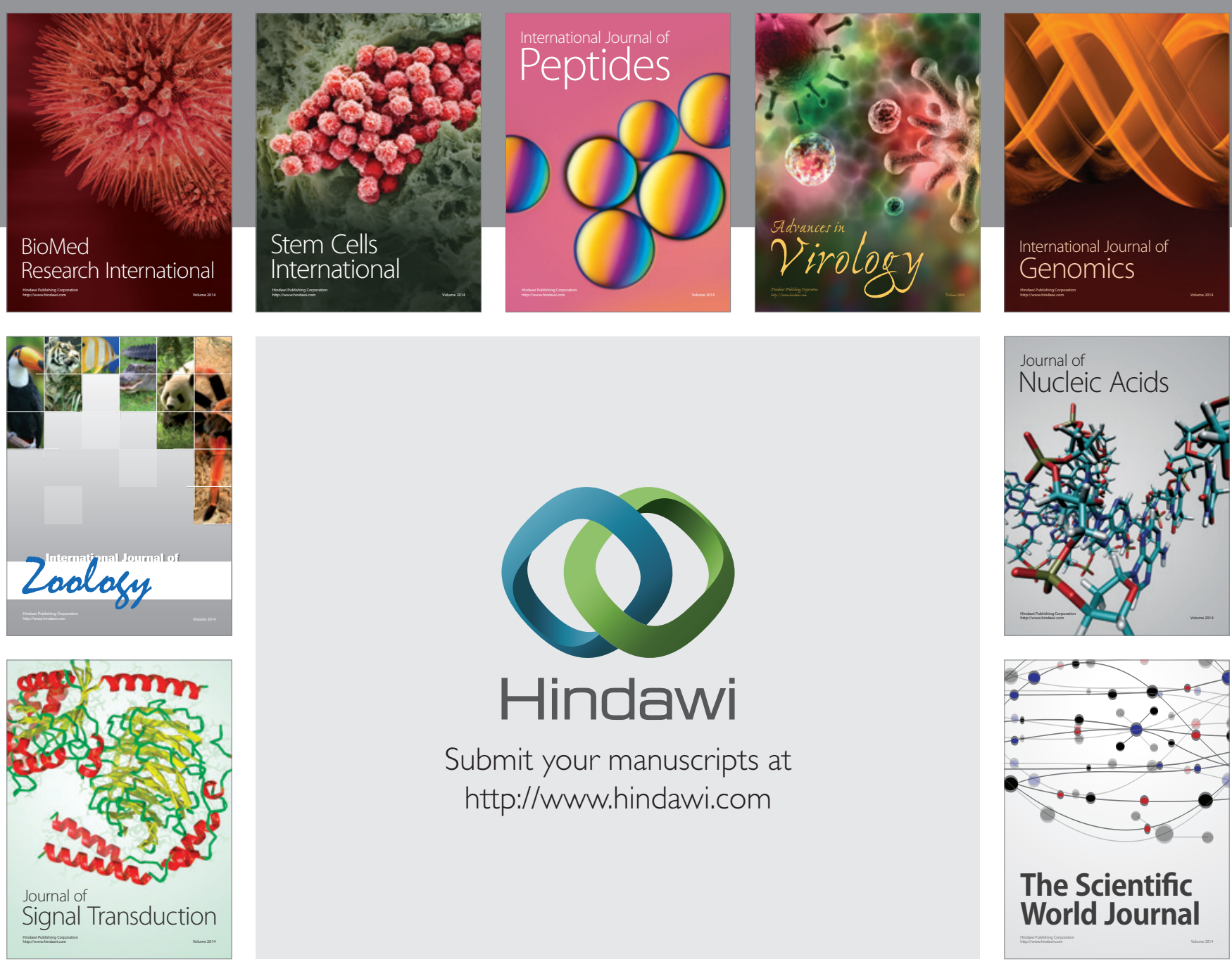

Submit your manuscripts at

http://www.hindawi.com
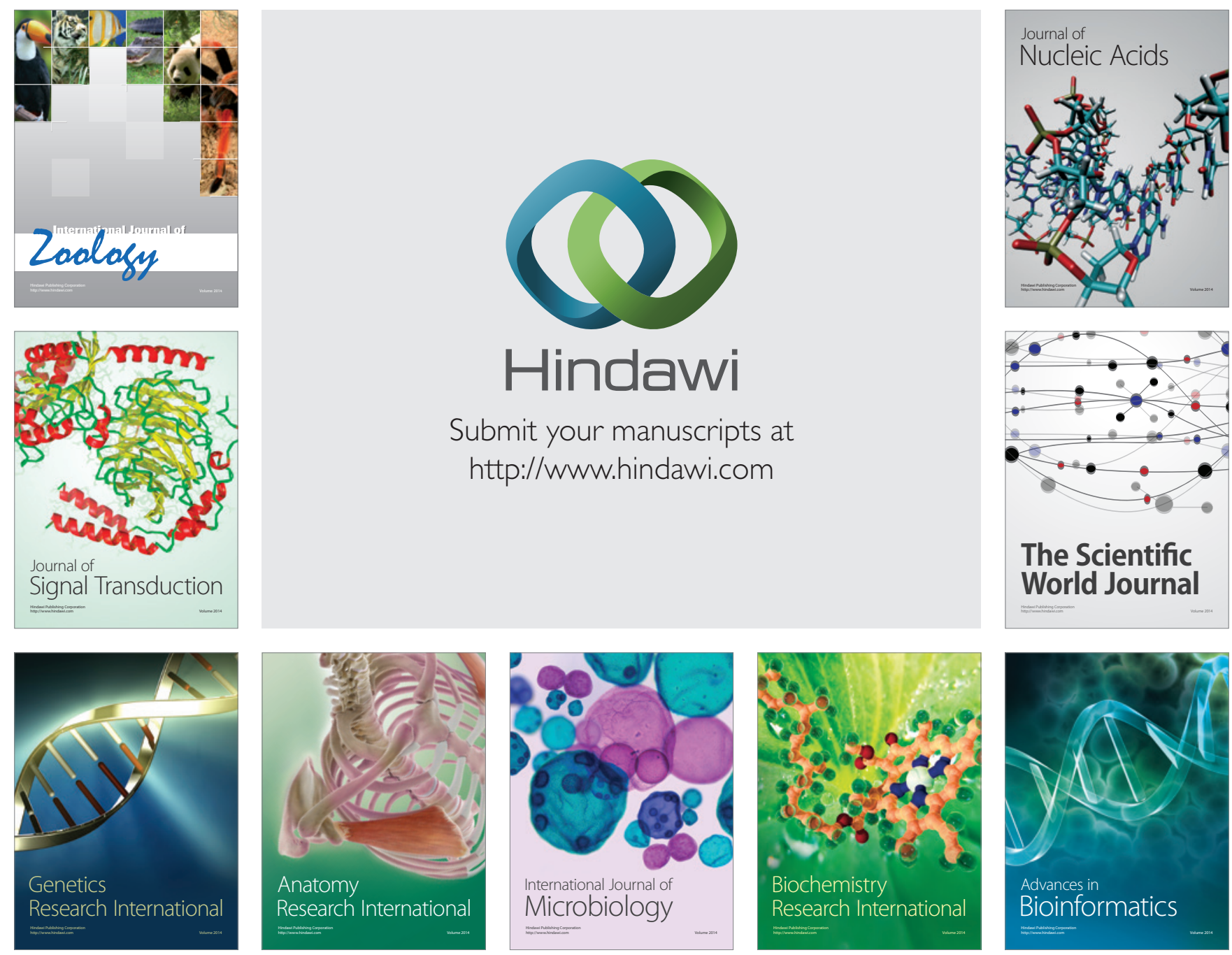

The Scientific World Journal
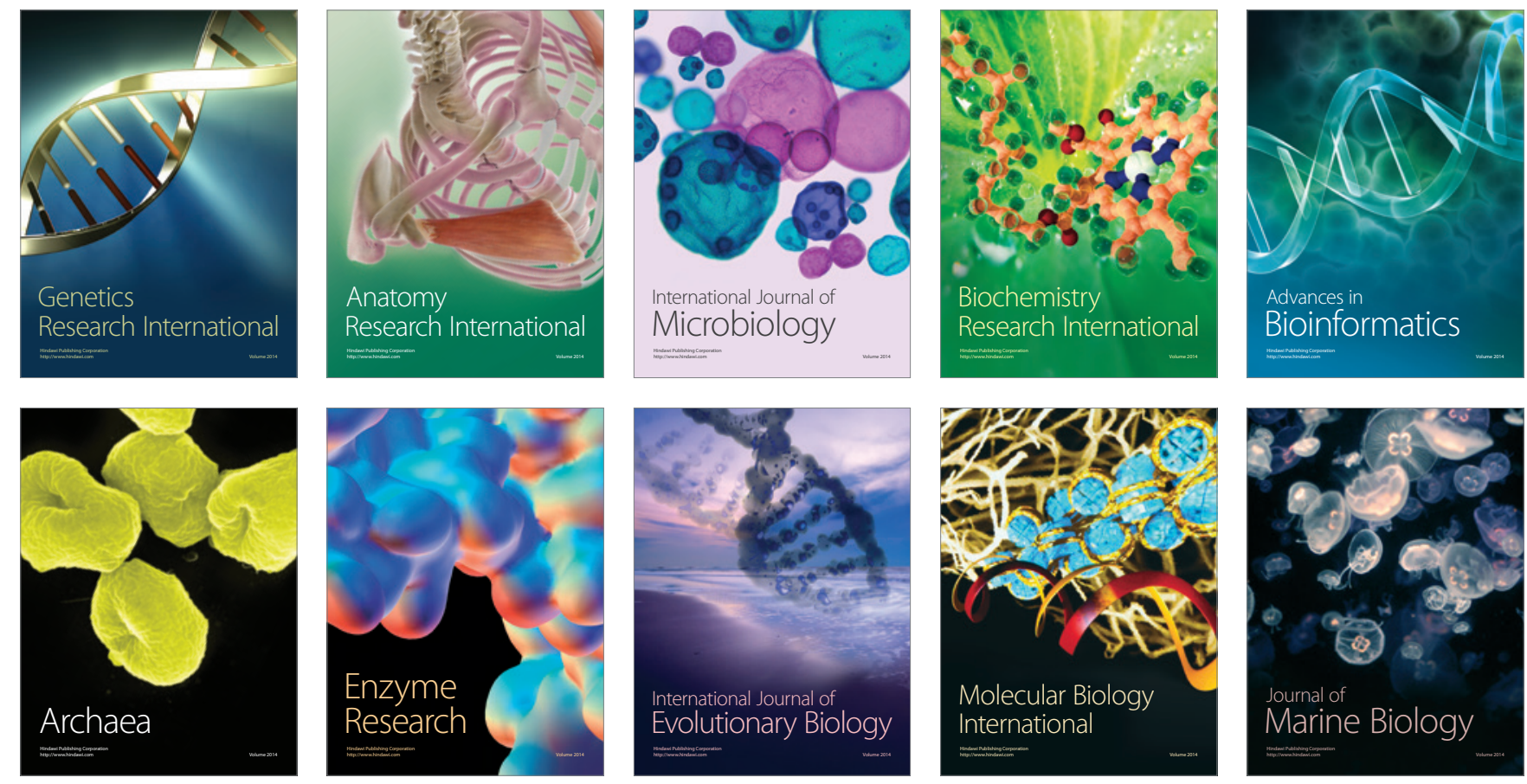